Arab World English Journal (AWEJ) Volume 12. Number2 June 2021

DOI: https://dx.doi.org/10.24093/awej/vol12no2.21

Pp.306 -317

\title{
Vocabulary Learning Strategies Used by Thai High School Students in Science, Language, and English Programs
}

\section{Panadda Thiendathong}

The Faculty of Humanities and Social Sciences, Mahasarakham University,

Maha Sarakham, Thailand

Correspondent author: panadda.d@msu.ac.th

\section{Apisak Sukying}

The Faculty of Humanities and Social Sciences, Mahasarakham University

Maha Sarakham, Thailand

Received: 3/7/2021

Accepted: 6/15/2021

Published:6/24/2021

\section{Abstract}

This study investigated the vocabulary learning strategies used by Thai high school students. The aim was to identify the frequency of different techniques used by high school learners studying in various programs. The main objective of this study was to compare the use of vocabulary learning strategies between multiple programs of study and examine the relationship between these different strategies. A total of 491 high school students from multiple academic disciplines participated in this study. A 47-item questionnaire of vocabulary learning strategies was given to the participants. In addition, qualitative data were collected via semi-structured interviews with 21 students to gain further information on their vocabulary learning strategy use. The interview recordings were immediately transcribed verbatim and translated from Thai into English by two experts. The results indicated that the most frequently used strategies were determination strategies, whereas memory strategies were used the least. The findings also showed that the learning context influenced the participants' use of vocabulary learning strategies. The qualitative results further revealed the variety of vocabulary learning strategies and the degrees of strategy use. In conclusion, this study highlighted that vocabulary learning strategies are interrelated, and the strategies adopted by learners can depend on vocabulary learning conditions. Keywords: conditions of vocabulary learning, English program, language program, science program, Vocabulary learning strategies

Cite as: Thiendathong, P., \& Sukying, A. (2021). Vocabulary Learning Strategies Used by Thai High School Students in Science, Language, and English Programs. Arab World English

Journal, 12 (2) $306-317$.

DOI: https://dx.doi.org/10.24093/awej/vol12no2.21 


\section{Introduction}

Developing English language competence for students in English as a foreign language (EFL) contexts has been a significant burden for English language teachers and researchers. In second language (L2) acquisition, vocabulary knowledge is an integral part of English language learning. According to Read (2000), vocabulary knowledge is essential for successful language learning as it assists language learners to comprehend the meaning of larger structures better. In other words, when language learners know many words in a target language, they are more comfortable using that language in both receptive and productive manners. Thus, it is suggested that effective vocabulary learning strategies need to promote vocabulary learning to improve students' language competence.

Schmitt (1997) defined vocabulary learning strategies (VLS) as tactics or actions that can help language learners acquire and retain vocabulary knowledge. Research on L2 vocabulary indicates that VLS plays a pivotal role in language learning (Nation, 2001). Specifically, VLS facilitates vocabulary knowledge and English language attainment. Students may use different strategies to acquire vocabulary knowledge if they feel those strategies are practical, functional, and suitable. Moreover, when learners are equipped with various methods, they can adapt the strategy according to the learning context.

Several long-term studies have been conducted to examine VLS in EFL contexts at a tertiary level (Fan, 2003; Kongthong, 2007; Siriwan, 2007; Bernardo \& Gonzales, 2009; Mustapha \& Asgari, 2010; Zhang, 2011; Heng, 2011; Pookcharoen, 2011; Komol \& Sripetpun, 2011; Han, 2014; Nirattisai \& Chiramanee, 2014; Boonkongsaen \& Intaraprasert, 2014; Saengpakdeejit, 2014; Rojananak \& Vitayapirak, 2015; Phonhan, 2016; Nie \& Zhou, 2017; Panduangkaew, 2018; Boonnoon, 2019). Other studies have assessed the frequency of VLS use and the relationship between VLS and other aspects such as academic field of study, learners' English proficiency, and gender. Although previous studies have addressed the use of VLS in EFL contexts, there has been no investigation on how different academic learning programs might influence students' use of vocabulary learning strategies at a secondary level.

\section{Literature review}

\section{Vocabulary Learning Strategies}

Many scholars have examined the development and the term of vocabulary learning strategies, and they have classified different taxonomies of VLS. Oxford (1990) presents a comprehensive taxonomy of VLS by dividing it into two main categories: direct strategies and indirect strategies. Gu and Johnson (1996) investigated the use of vocabulary learning strategies employed by Chinese learners and classified vocabulary learning strategies into eight categories as; belief about vocabulary learning, metacognitive regulation, guessing strategies, dictionary strategies, note-taking strategies, memory (using rehearsal) strategies, memory (using encoding) strategies, and activation strategies. Furthermore, Lawson and Hogben (1996) divided VLSs into four broad categories. The individual VLSs were classified under four categories: repetition, word feature analysis, simple elaboration, and complex elaboration.

Schmitt (1997) developed and classified vocabulary learning strategies, adapted from Oxford's, into five subcategories under two main categories; Determination, Social, Memory, Cognitive, and Metacognitive strategies. Determination strategies occur when learners encounter 
discovering the meaning of a new word without resorting to any help from another person's experience. Social strategies pertain to learning a new word by interaction with others. Memory strategies emerge when learners link their learning of a new word by associating their previous knowledge with a new word. Cognitive strategies are relevant to the repetition and employing mechanical means for vocabulary learning. Lastly, metacognition strategies entail a consciousness used in the learning process and help students use the best study methods.

Nation (2001) classified his taxonomy by distinguishing between the sources of vocabulary knowledge and learning processes. Thus, three classes of vocabulary learning strategies: planning, sources, and processes.

\section{Method}

This study examined the frequency with which Thai high school students used VLS when learning new words and retrieving the meaning of learned words. It also examined the differences in strategies used across study programs and the relationships between strategy. Descriptive and inferential statistics were used to analyze the data.

\section{Participants and Settings}

The participants were $491 \mathrm{EFL}$ students, ranging from 15 to 18 years of age, in three study programs from two public high schools in northeastern Thailand. The participants included 180 Science program students, 184 Language program students, and 127 English program students. The Science program included subjects in Physics, Chemistry, Biology, and Mathematics, whereas the Language program included the compulsory subjects and foreign languages such as Chinese, Japanese, French. Finally, English program students studied English, Mathematics, Science, Social studies, Home Economics, Physical Education, Computer, and Arts in the English language with native speakers. They also studied the Thai language and some social studies in their native Thai language.

All participants in this study had studied English as a foreign language since primary school and, as such, they had at least nine-year experience in learning English. It was assumed that all participants had a similar background in English language learning regarding their learning experiences within a school context. Moreover, throughout the nine years' experience in learning the English language, the participants in this study were in compulsory education, which provided similar subjects and content.

In a section of the questionnaire, the participants were asked if they were available to provide further information in a personal interview a week after completing the questionnaire and, if so, to provide their telephone number. Galvin (2015) suggests that seven to eight interviews suffice for descriptive studies. Accordingly, 21 participants ( 7 from each study program) completed the interview process.

\section{Instruments}

Vocabulary Learning Strategy Questionnaire

The 47-item questionnaire used in this study was adapted from Schmitt's (1997) taxonomy of VLS, and the items were classified under five categories: determination, social, memory, cognitive, and metacognitive. The questionnaire was divided into two parts: the participant's 
personal information and the participants' VLS use, which was assessed using a 6-point Likert's scale from 0 (never), 1 (rarely), 2 (sometimes), 3 (often), 4 (usually), to 5 (always). The questionnaire was translated into Thai by two certified English-Thai translators to ensure that all the participants understood the items.

\section{Semi-structured interview}

Semi-structured interviews allow individuals to show their independent thinking without confronting peers in a focus group and provide an opportunity to explore the participants' responses. In the current study, the beginning of the interview entailed general questions to establish a positive relationship between the interviewer and the interviewees. The interview questions focused on the strategies that the students employed to know the meaning of unknown words and when they want to retain the meaning of the newly learned words. The students' rationale for using these strategies was also probed. Regarding the reliability and validity of the interview questions, the question items were translated into Thai by two certificated EnglishThai translators and assessed by five experts in English Language Teaching.

\section{Procedures}

Before the main study, a questionnaire was piloted with a cohort of participants who had similar characteristics. None of these participants was involved in the main study. In the main study, the data were collected using a questionnaire on VLS. The participants took approximately 20 minutes to complete the questionnaire, including the time required to explain the questionnaire's items. Then, 21 students were randomly selected to participate in a semistructured interview, which occurred one week after completing the questionnaire. These interviews were conducted in Thai and lasted approximately 45 minutes for each student. The interviews were recorded and immediately transcribed verbatim for the data analysis.

The completed questionnaires were tallied and tabulated using the Statistical Package for the Social Sciences (SPSS) to identify the students' VLS use. Descriptive statistics, including means and standard deviation (S.D.) for each item, were calculated to determine the participants' use of VLS. A one-way ANOVA and Fisher's least-significant difference test (LSD) were used to determine any differences in VLS use between the three study programs. Correlations were also calculated to show the relationship between strategic vocabulary learning between these groups.

\section{Results}

Thai High School Learners' VLS Use

Table 1 summarises the results of the questionnaire for the overall VLS use in Thai high school participants. The results showed that the most frequently used strategy by Thai high school participants was determination strategies $(\mathrm{DET}, 54.66 \%, \mathrm{SD}=0.698)$, followed by metacognitive strategies (MET, 52.83\%, SD =0.893), social strategies $(\mathrm{SOC}, 49.50 \%, \mathrm{SD}=$ $0.877)$ and cognitive strategies $(\mathrm{COG}, 49.50 \%, \mathrm{SD}=0.860)$ and, finally, memory strategies (MEM, $47.83 \%, \mathrm{SD}=0.760$ ). The current findings suggest that Thai high school participants exploit all VLS. 
Arab World English Journal (AWEJ) Volume 12. Number 2. June 2021

Vocabulary Learning Strategies Used by Thai High School

Thiendathong \& Sukying

Table 1. Vocabulary Learning Strategies $(V L S)$ used by high school learners $(n=491)$

\begin{tabular}{lcccl}
\hline Vocabulary Learning Strategies & $\bar{X}$ & $\%$ & S.D. & Meaning \\
\hline Determination strategy (DET) & 3.28 & 54.66 & .698 & often \\
Metacognitive strategy (MET) & 3.17 & 52.83 & .893 & often \\
Social strategy (SOC) & 2.97 & 49.50 & .877 & often \\
Cognitive strategy (COG) & 2.97 & 49.50 & .860 & often \\
Memory strategy (MEM) & 2.87 & 47.83 & .760 & often \\
\hline
\end{tabular}

To gain further insight into high school students' VLS use, the student's responses in the interviews were transcribed verbatim and then translated from Thai into English for data analysis. The table below shows a sample of the interview excerpts from students in each study program for the five types of strategies.

Table 2. The students' interview excerpt about Determination strategies (DET) use

\begin{tabular}{cl}
\hline Study programs & \multicolumn{1}{c}{ VLSs } \\
\hline Science & - I mostly use a bilingual dictionary and an online dictionary to know the meaning \\
& because it is convenient. (S1) \\
& - I use an online dictionary on my cell phone (Longdo) because it provides L1 \\
& translation and synonyms, which are very useful. I also make use of a word's \\
& contexts and sentence structures to help me guess the meaning of a word. (S2) \\
\hline Language & - I guess from the context and its image. They help me guess the meaning of the \\
& word. (L1) \\
& - I use an online dictionary on my phone. (L2) \\
\hline English & $\begin{array}{l}\text { I use Google translation and an online dictionary on my cell phone because it is } \\
\text { effortless and fast. (E1) }\end{array}$ \\
& - I use an online dictionary, and I often guess the word's meaning by guessing its \\
& context. I see it is constructive. (E2)
\end{tabular}

Table 3. The students' interview excerpt about Social strategies (SOC) use

\begin{tabular}{cll}
\hline Study programs & \multicolumn{1}{c}{ VLSs } \\
\hline Science & $\begin{array}{l}\text { I ask my teacher for the meaning and synonyms of the words, and I ask my friends } \\
\text { sometimes. (S3) } \\
\text { I prefer asking my friends to my teacher because my teacher does not seem to understand } \\
\text { me. (S4) }\end{array}$ \\
\hline Language & $\begin{array}{l}\text { I like to ask my friends and my English teacher for the definition and further examples } \\
\text { because I feel they are creditable to me. (L3) }\end{array}$ \\
& $\begin{array}{l}\text { I learn new words by asking friends and teachers in the classroom because I cannot } \\
\text { concentrate on the lessons alone. So, I better learn by asking other people. I also talk with } \\
\text { my foreign friends. Whenever I see unknown words, I note them on my cell phone and } \\
\text { have foreigners explain their meaning. I feel much comfortable having friends define to } \\
\text { me, and this strategy always works for me. (L4) }\end{array}$ \\
\hline English & $\begin{array}{l}\text { When I struggle with any unknown words, especially in a science class, I ask my English } \\
\text { teacher for a word's meaning, hints, and synonyms. They help me better understand the } \\
\text { word and the content. (E3) }\end{array}$ \\
& I ask my teacher for a meaning of a word. (E4)
\end{tabular}


Arab World English Journal (AWEJ) Volume 12. Number 2. June 2021

Vocabulary Learning Strategies Used by Thai High School

Thiendathong \& Sukying

Table 4. The students' interview excerpt about Memory strategies (MEM) use

\begin{tabular}{|c|c|}
\hline $\begin{array}{c}\text { Study } \\
\text { programs }\end{array}$ & VLSs \\
\hline Science & $\begin{array}{l}\text { - I try to use sounds and images to help me remember. For example, the word "Ant" - I try } \\
\text { to imagine an ant whose head looks like the shape of the alphabet A- in the word "ant". It } \\
\text { is pretty complicated but beneficial to me. I also study its pronunciation. I remember } \\
\text { vocabulary by mapping, grouping. I always do mapping and grouping because it helps me } \\
\text { recognize and connect to other related words. (S5) } \\
\text { - I say the word aloud and think about the image of a word to remember the meaning. I } \\
\text { group words in the same categories. I also use the words in sentences. (S6) }\end{array}$ \\
\hline Language & $\begin{array}{l}\text { - I draw pictures to help me remember. In my opinion, these strategies suit me well, and } \\
\text { they are beneficial to me. (L5) } \\
\text { - I sort the vocabulary by its categories. When I get used to these strategies, they help me a } \\
\text { lot, and I can remember the vocabulary well from them, and I can use the vocabulary } \\
\text { better in my speaking. (L6) }\end{array}$ \\
\hline English & $\begin{array}{l}\text { I make up a story and think about real situations containing words to help me recall the } \\
\text { meaning. (E5) } \\
\text { - I remember from images, letters, positions of the word on a page, alphabetical order. (E6) }\end{array}$ \\
\hline
\end{tabular}

Table 5. The students' interview excerpt about Cognitive strategies (COG) use

\begin{tabular}{|c|c|}
\hline $\begin{array}{c}\text { Study } \\
\text { programs }\end{array}$ & VLSs \\
\hline Science & $\begin{array}{l}\text { - I often study and revise the learned vocabulary from the student's book. Also, I use a } \\
\text { highlighter pen because I think colors work well with my brain, helping me recognize } \\
\text { vocabulary well. It is beneficial to me. (S7) } \\
\text { I also have a mini-book for jotting down the unknown words. I usually repeat the } \\
\text { vocabulary to help me remember when I have a vocabulary quiz. I also use a highlighter } \\
\text { pen to highlight and revise them to help me remember. (S8) }\end{array}$ \\
\hline Language & $\begin{array}{l}\text { - I use post-it papers when studying wordlist, I have found that I can revise better. I also say } \\
\text { the vocabulary out many times to remember. I like to use a highlighter pen when studying } \\
\text { words. (L7) } \\
\text { - I just jot down the vocabulary and revise it to help me remember. (L8) }\end{array}$ \\
\hline English & - I study Ultimate Vocab for Academics. I have a notebook to jot down; it helps. (E7) \\
\hline \multicolumn{2}{|c|}{ Table 5. The students' interview excerpt about Cognitive strategies (COG) use } \\
\hline $\begin{array}{c}\text { Study } \\
\text { programs }\end{array}$ & VLSs \\
\hline Science & $\begin{array}{l}\text { - I revise vocabulary once a week. I watch soundtrack movies, online } \\
\text { VDOs, and listen to music. When I see unknown words, I jot down and } \\
\text { find the meaning later. I also do extensive reading with Harry Potter to } \\
\text { improve my English. (S9) } \\
\text { - I often watch soundtrack movies and read online novels. I learn } \\
\text { vocabulary with these strategies because they are relaxing, and I am keen } \\
\text { on them. I also say the word and try to use vocabulary that I learned to } \\
\text { practice English. These strategies are helpful to me. (S10) }\end{array}$ \\
\hline Language & $\begin{array}{l}\text { - I watch cartoons, English series, and English movies on Netflix to help me } \\
\text { learn and improve my English vocabulary. I watch these because I like }\end{array}$ \\
\hline
\end{tabular}


Arab World English Journal (AWEJ) Volume 12. Number 2. June 2021

Vocabulary Learning Strategies Used by Thai High School

Thiendathong \& Sukying

\begin{tabular}{cc}
\hline Study & VLSs \\
programs & \\
\hline
\end{tabular}

entertaining, and I have a passion for learning English with entertainment. In addition, recently, these things are easily accessible and valuable for improving English skills. (L9)

- I always read books to revise the lessons by myself. I also learn new vocabulary from the Internet, YouTube, VDO, online news about celebrities. I am interested in this entertainment. So, I can learn English vocabulary happily. (L10)

English $\quad$ I like to watch movies, listen to English songs, and read books. When I learn by myself, I better remember. I like to listen to it over time because it helps me with the accent. (E8)

- I am obsessed with reading online novels. I also watch English movies because it is easily accessible. (E9)

\section{Comparing VLS use between study programs}

Figure 1 summarizes the use of VLS among the three study programs (science, language, and English). It appears that students from all three study programs used various strategies to learn English vocabulary. The results indicate that students in the science and language programs had a similar pattern of VLS use; however, the English program students appeared to use VLS more than students in the other two study programs.

Table 7. Comparing Vocabulary Learning Strategies (VLS) use between study program

\begin{tabular}{llcccccc}
\hline \multicolumn{1}{c}{ VLSs } & Study Program & $\mathbf{N}$ & $\mathbf{\%}$ & $\bar{x}$ & $\mathbf{S . D}$ & $\mathbf{F}$ & Sig. \\
\hline determination strategy (DET) & Science program & 180 & 53.50 & 3.21 & .662 & & \\
& Language program & 184 & 53.66 & 3.22 & .710 & 5.369 & $.005^{*}$ \\
& English program & 127 & 57.50 & 3.45 & .709 & & \\
\hline social strategy (SOC) & Science program & 180 & 47.00 & 2.82 & .875 & & \\
& Language program & 184 & 47.50 & 2.85 & .870 & 16.836 & $.000^{*}$ \\
& English program & 127 & 55.66 & 3.34 & .781 & & \\
\hline memory strategy (MEM) & Science program & 180 & 46.83 & 2.81 & .736 & & \\
& Language program & 184 & 46.16 & 2.77 & .768 & 8.587 & $.000^{*}$ \\
& English program & 127 & 51.83 & 3.11 & .737 & & \\
\hline cognitive strategy (COG) & Science program & 180 & 49.16 & 2.95 & .897 & & \\
& Language program & 184 & 48.33 & 2.90 & .847 & 2.498 & .083 \\
& English program & 127 & 51.83 & 3.11 & .815 & & \\
\hline metacognitive strategy (MET) & Science program & 180 & 50.66 & 3.04 & .869 & & \\
& Language program & 184 & 51.66 & 3.10 & .930 & 9.544 & $.000^{*}$ \\
& English program & 127 & 57.66 & 3.46 & .807 & & \\
\hline
\end{tabular}

Note: *. The mean difference is significant at the 0.05 level.

Overall, English students used the metacognitive strategy more than the other strategies (57.66 $\%, \bar{x}=3.46, \mathrm{SD}=0.807$ ), whereas language and science program students showed a preference for determination strategies over other strategies $53.66 \%, \bar{x}=3.22, \mathrm{SD}=0.71$ and $53.5 \%, \bar{x}=$ $3.21, \mathrm{SD}=0.662$, respectively). The results also show no distinct difference in cognitive strategy use among the students in this study. 
Moreover, the results indicate that English program students were more likely than science and language students to use determination strategies, social strategies, memory strategies, cognitive strategies, and metacognitive strategies. Indeed, a one-way ANOVA confirmed that VLS use differed significantly between study programs. Specifically, Post-hoc tests showed that the English-program students employed significantly more determination strategies (DET), social strategies (SOC), memory strategies (MEM), and metacognitive strategies (MET) than those from science-program and language-program.

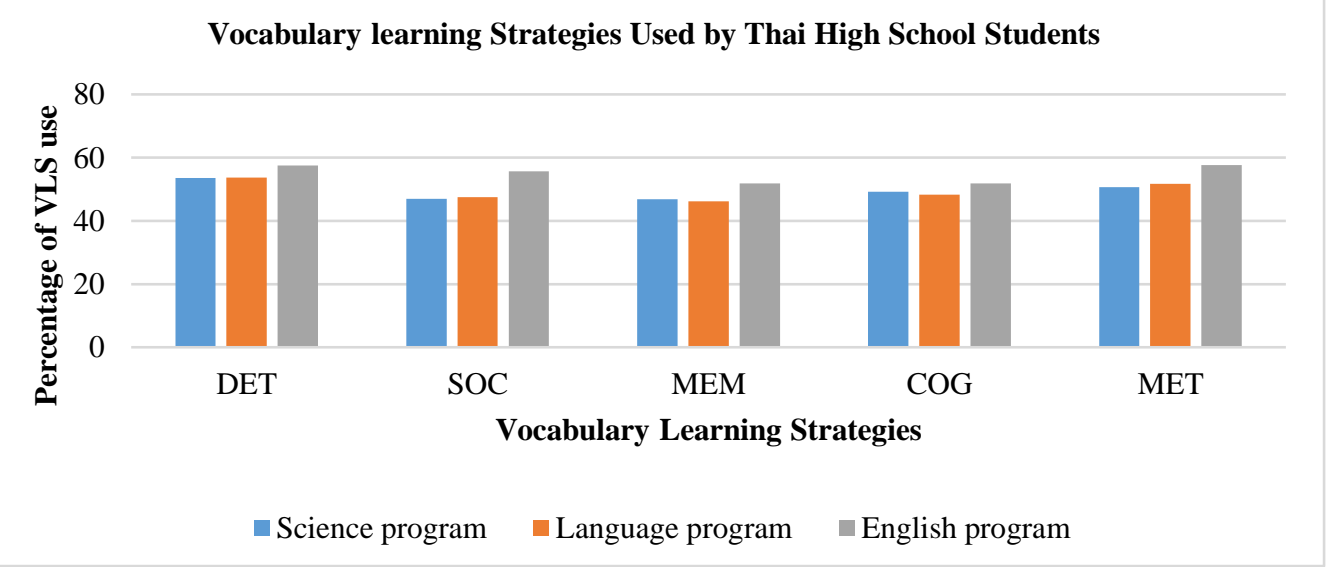

Figure 1. Comparison of VLS use between study programs

\section{Relationship between Vocabulary Learning Strategies}

Table 2 shows the results of the correlational analysis. It was found that the strategies were positively correlated, with a medium to a high degree of correlation among all five categories. Specifically, there was a strong correlation between the DET and the MEM $(r=0.562)$, the DET and the MET ( $r=0.507)$, the SOC and the MEM $(r=0.603)$, the SOC and the COG $(r=0.513)$, the MEM and the COG $(r=0.665)$, the MEM and the MET $(r=0.577)$, and the COG and the MET $(r=0.585)$. The relationship between the DET and the SOC $(r=0.397)$, the DET and the COG $(r=0.474)$, and the SOC and the MET $(r=0.425)$ were considered medium-strength relationships.

Overall, the correlational analysis revealed significant relationships between different VLS. The correlation between memory strategies (MEM) and cognitive strategies was the highest $(r=$ 0.665), suggesting that these strategies are often used in conjunction. By contrast, the correlation between the determination strategies (DET) and the social strategies (SOC) was the lowest $(r=$ 0.397), indicating that students are less likely to employ both of these strategies.

Table 8. Correlations between vocabulary learning strategies (Pearson correlations, $r$ )

\begin{tabular}{llllll}
\hline VLSs & \multicolumn{3}{l}{ Correlations (r) } & & \\
& (DET) & (SOC) & (MEM) & (COG) & (MET) \\
\hline determination strategy (DET) & & $.397^{* *}$ & $.562^{* *}$ & $.474^{* *}$ & $.507^{* *}$ \\
social strategy (SOC) & & $.603^{* *}$ & $.513^{* *}$ & $.425^{* *}$ \\
memory strategy (MEM) & & & $.665^{* *}$ & $.577^{* *}$ \\
cognitive strategy (COG) & & & & $585^{* *}$ \\
metacognitive strategy (MET) & & & & &
\end{tabular}

Note: **. The correlation difference is significant at the 0.001 level (2-tailed). 


\section{Discussion}

\section{Thai High School Learners' VLSs Use}

This study explored Thai high school participants' vocabulary learning strategy use. Overall, the results indicate that Thai high school participants used determination strategies the most, followed by metacognitive strategies, social and cognitive strategies, and, finally, memory strategies.

Determination strategies were found to be the most frequently used by the participants in this study. It appears that these strategies are beneficial in assisting L2 learners when they face difficulties in understanding the meaning of unknown words. For example, using a dictionary, which falls in the determination category, is highly convenient, explaining its frequent use among students. In this study, the participants reported that they preferred bilingual dictionaries as they offer the learners' native language. These current findings are consistent with previous studies showing that learners can decode the meaning of new words by making use of textual contexts, using a bilingual dictionary, and analyzing any available pictures or gestures (Fan, 2003; Kongthong, 2007; Pookcharoen, 2011; Komol \& Sripetpun, 2011; Nirattisai \& Chiramanee, 2014; Rojananak \& Vitayapirak, 2015; Panduangkaew, 2018). The use of determination strategies, including using dictionaries, the context, word structures, and available references, was also reported in the semi-structured interviews, as shown in the following excerpts:

"I use an online dictionary on my cell phone (Longdo) because it provides L1 translation and synonyms, which are very useful. I also make use of a word's contexts and sentence structures to help me guess the meaning of a word." (S2)

"I guess from the context and its image. They help me guess the meaning of the word." (L1)

"I use Google translation and an online dictionary on my cell phone because it is effortless and fast." (E1)

"I mostly use a bilingual dictionary and an online dictionary when I want to know the meaning because it is convenient. (S1)"

By contrast, memory strategies were employed the least for vocabulary retention in the high school participants. This finding is consistent with a previous study that reported a low application of memory strategies (Fan, 2003). Memory strategies can be complicated to employ, which may explain their low frequency of use. Such strategies require complex mental processing, such as imagery, word association, and keyword methods (Schmitt, 2000). Indeed, memory strategies required that learners connect the newly learned word with their pre-existing knowledge or experience, which requires a high level of mental processing. Another reason for the low adoption of this strategy could be the substantial vocabulary that learners need to acquire. When there is an excessive load of word for EFL learners to remember, learners may avoid memory strategies, such as repetition. These results suggest that strategies that require time to create, learn, and practice, are not practical or straightforward to use for all learners.

However, other studies have reported that memory strategies are the most frequently used strategy, particularly in EFL settings (U-pitak, 2011; Heng, 2011). It may be due to the traditional English-language instruction commonly used in some EFL contexts, which mostly leads learners to perform rote learning. Moreover, in the qualitative findings, a few participants 
expressed the usefulness of the Keyword Method (a memory strategy) but did acknowledge its complexity, for example:

"I try to use sounds and images to help me remember. For example, the word "Ant" - I try to imagine an ant whose head looks like the shape of the alphabet A- in the word "ant." It is pretty complicated but beneficial to me." (S5)

\section{Comparing Strategies Used between Study Programs}

The current findings showed that the English program participants outperformed the science and language program participants in all VLS. These findings are in line with previous research, which reported significant differences in the use of VLS across academic majors (Bernardo \& Gonzales, 2009; Boonnoon, 2019). These findings might be explained by the disparity in the learning contexts of the three study programs. For instance, the English program might provide additional opportunities for students to use the English language due to the program's instruction. Indeed, in this program, several subjects are mainly instructed in the English language. Moreover, with authentic textbooks, the students have to deal with the natural language that native speakers employ in authentic contexts. Such programs also offer native English-speaking teachers and foreign teachers from various nationalities and cultures, encouraging English-program students to engage in meaningful conversations when learning word meanings in the classroom. English-program students are EFL learners pursuing English to learn English. The English program students need to strive in their learning contexts since more exposure also means more chances to meet a wide range of vocabulary. As a result, they may resort to using more VLS than other programs. For instance, asking teachers for help could help learners obtain a more transparent comprehension of the word's meaning in a natural context. The qualitative finding of the current study supports this claim:

"When I struggle with any unknown words, especially in a science class, I ask my English teacher for a word's meaning, hints, and synonyms. They help me better understand the word and the content." (E3)

The results from the questionnaire showed that the participants in the science and language programs had a similar pattern of VLS use. This finding is somewhat consistent with Phonhan (2016), who reported a non-significant difference in the use of VLS regarding language proficiency, gender, and fields of study. Similar learning contexts may explain this result. Indeed, while science and language program students are EFL learners, they use their native language to learn English. In other words, the students in both science and language programs use Thai to learn English. This context creates less English language exposure for the students in both learning programs of study, impacting their overall use of VLS.

\section{Relationship between Vocabulary Learning Strategies}

The correlational analysis revealed a significant positive relationship among all VLS. Indeed, all strategies presented a moderate to a high degree of correlation, indicating that the VLS were highly interrelated. Students are likely to employ more than one strategy when learning vocabulary and may use all types of VLS to acquire and learn the English vocabulary. It, therefore, appears that all strategies are closely related, which supports claims that VLS should be employed in combination rather than in isolation (Nie, 2017). In this study, memory and cognitive strategies were the most highly correlated. It suggests that the strategies of 
memorization could be a foundation for the use of other VLS. By contrast, determination and social strategies showed the weakest correlation, perhaps reflecting the different characteristics of these strategies. The determination strategy is used when learners discover the meaning of an unknown word alone, whereas the social strategy relies on interacting with others to obtain and retain vocabulary. Nevertheless, these two strategies still shared a moderate, positive relationship, indicating that all categories of VLS can be employed together.

\section{Conclusion}

The present study investigated the vocabulary learning strategies in Thai high school learners across different learning programs and found the differences between the vocabulary learning strategies used in various academic programs. The quantitative results of this study revealed that the use of determination strategies was the most, whereas the least frequently employed strategies were the memory category. In terms of the most commonly used strategies, these findings confirmed the findings of previous studies (Fan, 2003; Kongthong, 2007; Pookcharoen, 2011; Komol \& Sripetpun, 2011; Nirattisai \& Chiramanee, 2014; Rojananak \& Vitayapirak, 2015; Panduangkaew, 2018). The use of each strategy depends on various rationales. The current results also found that English-program students outshined science-program students and language-program students in strategic use. Besides, correlation analysis indicated that strategies were interrelated.

\section{About the Authors:}

Apisak Sukying is an assistant professor in ELT at Mahasarakham University, Thailand. Apisak completed his Ph.D. in TESOL from the University of Sydney, Australia. His research interests are L2 vocabulary acquisition and development, L2 vocabulary testing, academic writing, SLA, EAP, ESP and language learner strategies. https://orcid.org/0000-0002-2553-0433

Panadda Thiendathong is a postgraduate student in English Language Teaching Programme at Mahasarakham University, Thailand. Panadda has been an English teacher in a high school for almost ten years. Her interests are L2 vocabulary acquisition and learning behavior.

\section{References}

Asgari, A., \& Bin Mustapha, G. (2010). The type of vocabulary learning strategies used by ESL students in University Putra Malaysia. English Language Teaching, 4(2), 84-90. https://doi.org/10.5539/elt.v4n2p84.

Boonkongsaen, N., \& Intaraprasert, C. (2014). Use of English vocabulary learning strategies by Thai tertiary-level students in relation to fields of study and language-learning experiences. English Language Teaching, 7(5), 59-70. http://dx.doi.org/10.5539/elt.v7n5p59

Boonnoon, S. (2019). Vocabulary learning strategies employed by Thai university students across four academic profiles. Theory and Practice in Language Studies, 9(8), 902-910.

Fan, M. Y. (2003). Frequency of use, perceived usefulness, and actual usefulness of second language vocabulary strategies: A study of Hong Kong learners. The Modern Language Journal, 87, 222-241.

Galvin, R. (2015). How many interviews are enough? Do qualitative interviews in building energy consumption research produce reliable knowledge? Journal of Building Engineering, 1, 2-12. DOI: 10.1016/j.jobe.2014.12.001 
Gu, P. Y., \& Johnson, R. K. (1996). Vocabulary learning strategies and language learning outcomes. Language Learning, 46(4), 643-679.

Heng, K. (2011). Effective vocabulary learning strategies: Perspectives from Cambodian students and teachers. [Master dissertation, Loyal University of Phnom Penh Institute Foreign Language Department of English].

Komol, T. \& Sripetpun, W. (2011, April). Vocabulary learning strategies employed by undergraduate students and its relationship to their vocabulary knowledge. Proceeding from the $3^{\text {rd }}$ International Conference on Humanities and Social Science (pp. 1-18). Faculty of Liberal Arts, Prince of Songkla University, Thailand.

Kongthong, J. (2007). A survey study of L2 vocabulary learning strategies of $4^{\text {th }}$-year students, the Faculty of Fine Arts, at Rajamangala University of Technology Tawan-Ok Chakrabongse Bhuvanarth campus. [Master dissertation, Thammasat University].

Lawson, J. M., \& Hogben, D. (1996). The vocabulary learning strategies of foreign-language students. Language Learning, 46(1), 101-135.

Nation, P. (2001). Learning vocabulary in another language. Cambridge University Press.

Nie, Y., \& Zhou, L. (2017). A study of vocabulary learning strategies used by excellent English learners. Research on Modern Higher Education, 4, 101106.10.24104/rmhe/2017.04.02010

Nirattisai, S., \& Chiramanee, T. (2014). Vocabulary learning strategies of Thai university students and its relationship to vocabulary size. International Journal of English Language Education, 2(1), 273-287

Oxford, L. R. (1990). Language learning strategies: What every teacher should know. Heinle \& Heinle Publishers.

Panduangkaew, R. (2018). An analysis of vocabulary learning strategies employed by Thai EFL undergraduates: Dictionary use. reFLections, 25(1), 116-125.

Phonhan, P. (2016). Language learning strategies of EFL education students: A case study of Thai undergraduate students. Journal of Social Sciences, Humanities, and Arts, 16(2), 115135.

Pookcharoen, S. (2011). Thai EFL undergraduates' vocabulary learning strategies: Perception and practice. Journal of English Studies, 6, 31-53.

Read, J. (2000). Assessing vocabulary. Cambridge University Press.

Rojananak, K., \& Vitayapirak, J. (2015). Comparison of English vocabulary learning strategies for good and weak learners at King Mongkut's Institute of Technology Ladkrabang. International Journal of Languages, Literature and Linguistics, 1(1), 1-5.

Rubin, J. (1975). What the good language learner can teach us. TESOL Quarterly, 9(1), 41-51.

Saengpakdeejit, R. (2014). Awareness of vocabulary learning strategies among EFL students in KhonKaen University. Theory and Practice in Language Studies, 4(6), 1101 -1108.

Schmitt, N. (1997). Vocabulary learning strategies. In N. Schmitt \& M. McCarthy (Eds.), Vocabulary: Description, Acquisition, and Pedagogy (pp.199-227). Cambridge University Press.

Schmitt, N. (2000). Vocabulary in language teaching. Cambridge University Press.

Siriwan, M. (2007). English vocabulary learning strategies employed. [Doctoral Dissertation, Suranaree University of Technology Nakhonratchasima].

Zhang, Y. (2011). The use of vocabulary learning strategies by good and poor language learners: A case study of Chinese non-English major sophomores. Kristianstad University School of teacher education. 